\title{
On the methodology for considering scale effect of rock strength
}

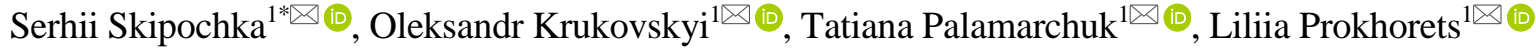 \\ ${ }^{1}$ Institute of Geotechnical Mechanics named by N. Poljakov of National Academy of Sciences of Ukraine, Dnipro, 49005, Ukraine \\ *Corresponding author: e-mail skipochka@ukr.net, tel. +380661079153
}

\begin{abstract}
Purpose is to improve a methodology for considering the influence of scale effect by transferring to the evaluation of rock strength immediately within the rock mass.

Methods. The research involves methods of critical analysis, theoretical and experimental research methods in the laboratory and full-scale conditions. In particular, there are statements of probabilistic and statistic theory, standard strength tests of rock specimens, laboratory studies of coal cutting resistance, and evaluation of rock strength by impact pulsing within the rock mass.

Findings. It has been determined that rock strength depends considerably on the sizes of specimens being tested. That is stipulated by high porosity and fissility of the material. Measurement error decreases along with the increasing specimen size. There is the ultimate size, beginning from which its following increase does not results in considerable changes in the strength indices. For instance, in terms of Western Donbas coals, such an ultimate size is represented by a cube with the faces of not less than $100 \mathrm{~mm}$. It has been shown that despite its high density, considerable scale effect is observed in hard rock as well; the effect is stipulated by the available zones with anomalously high porosity and coarse grains. It has been specified that minimum sizes of specimen faces for hard rock should be not less than 150-200 mm. Tests of such specimens are rather labour-intensive; they are often beyond the capacities of standard equipment. It has been concluded that structural anomalies of rocks require application of the methods which help evaluate their strength immediately within the rock mass; impact pulsing is one of those methods.
\end{abstract}

Originality. Minimum sizes of hard rock specimens and rock formations, making it possible to exclude the influence of scale effect of strength, have been identified. Correlation dependences, connecting the informative parameter of the impact pulse method with the strength of different rock lithotypes, have been obtained.

Practical implications. Methodologies for both considering scale effect of strength during laboratory studies and evaluating rock strength within the rock mass have been improved.

Keywords: rock, strength, cutting resistance, scale effect, laboratory measurements, mine control

\section{Introduction}

Mining operations are in the top ten most dangerous industries. According to the statistics, most accidents at mines are related to the geomechanical safety of the working environment. There are following main factors of geomechanical safety: static and dynamic manifestations of rock pressure, stability of underground mine workings, roof caving, loss of bearing capacity of supports and protective structures. Countries with the developed mining industry solve those problems by implementing geomechanical monitoring, which provides systematic control, evaluation, and prognosis of geomechanical state of the rock masses.

It is important that the monitoring elements will be adapted to the mining and geological conditions and mining technologies. Specification of the physical and mechanical characteristics of rock is the first and one of the topmost elements of the geomechanical monitoring. Correct design solutions, proper substantiation of the selected mining tech- nologies, methods, and means of mining operations depend on the accuracy and speed of such information gaining.

The most problematic issues in the methodology of evaluation of physical and mechanical rock properties are the ones concerning the consideration of scale factor of strength as well as operativity of the control of elastic and strength parameters of the rock mass in the laboratory and mine conditions. Figure 1, taken from paper [1], illustrates the influence of size of the rock mass under analysis on the rock strength.

The available scale effect of strength is explained by the nonuniformity and fissility of the rock mass [2][4]. The effect is observed depending on the deformation properties of the bodies and their volume. In this context, along with the increasing volume, the strength decreases nonlinearly, approaching asymptomatically some boundary $\sigma_{\min }$. That value may be considered as the true parameter of rock strength within the rock mass. 


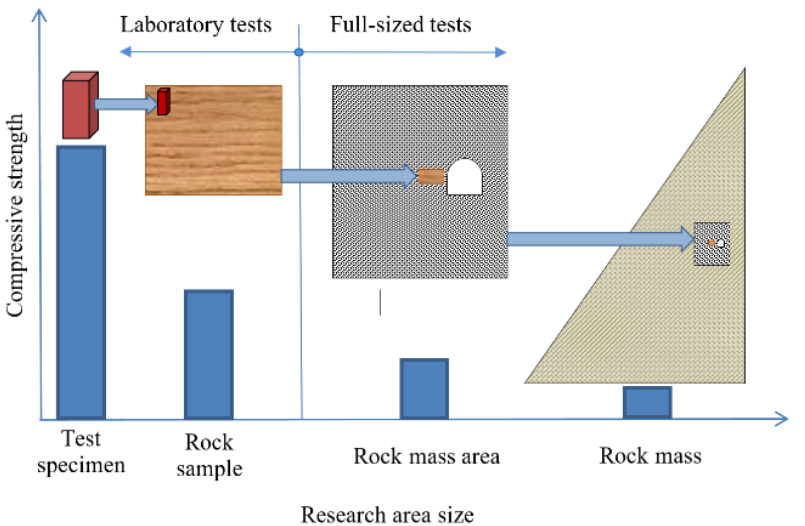

Figure 1. Illustration of the effect of the research area size on its strength

There are a number of methods to define scale effect of strength. However, some of them deal with the consideration of the factor during the laboratory studies, e.g. physical tests or mathematical modeling [5][10]. The research focuses on the improvement of the methodology for considering (in the ideal case, for excluding) the influence of scale effect by transferring to the evaluation of rock strength immediately within the rock mass.

Following research tasks are set in the paper:

- to identify the dependence of the rock strength value on the dimensions of specimens being tested;

- to substantiate the nature of high indices of scale effect of strength in hard rocks;

- to adapt one of the methods of non-breaking control applied in the construction industry for the evaluation of rock strength within the mass;

- to carry out comparative analysis of the indices of scale coefficient of strength for the specimens of standard dimensions and samples taken immediately within the rock mass.

\section{Methodology}

\subsection{Methods}

The paper involves methods of critical analysis as well as theoretical and experimental research methods in both laboratory and mine conditions.

Theoretical studies are based on the fact that the scale effect is of probabilistic nature. According to the theory by M.A. Sadovskii, rock mass is a self-similar (fractal) structure. Each case of hierarchy is defined by duplication of the length of a structural element. We can observe certain invariance of the geometry of fissures in rocks relative to the scale of analysis. That helps transfer the results of fissure studies at a microlevel to a meso- and macrolevel.

Laboratory tests were carried out in terms of a strength plant of "rigid" type with maximum effort of $450 \mathrm{kN}$. The studies involved rocks of coal, iron ore, and uranium deposits of Ukraine. The specimens were made in the form of cubes with the face dimensions from 20 to $150 \mathrm{~mm}$. Range of rock strength was from 5 to $200 \mathrm{MPa}$. Moreover, scale effect of the "cutting resistance" parameter has been analyzed, which is in close correlation with the ultimate strength of rocks. The studies were performed in terms of coal blocks of about $0.7 \times 0.5 \times 0.5 \mathrm{~m}$ using special equipment of V. Bakul Institute for Superhard Materials of the National Academy of Sciences (NAS) of Ukraine. The blocks were sampled at Ternivska mine of Western Donbas. While measuring coal cutting resistance, three force components within a cutter $\left(P_{x}, P_{y}, P_{z}\right)$ were being registered. Cutting depth experienced discrete variations from 5 to $30 \mathrm{~mm}$.

The results were compared with the data obtained in the mine conditions by specialists with the equipment by DMT $\mathrm{GmbH}$ (Germany). At the same time, coal samples were being taken within the same site; further, their strength was defined in terms of the specimens with the edges of 40,60 , 70, 80, 90, 100, and $150 \mathrm{~mm}$.

A method of impact pulse has been selected among the methods of non-breaking rock control. The developed methodologies and equipment were adapted for the conditions of mining production and for the rocks with strength range from 1 to $200 \mathrm{MPa}$ [11]. All the full-sized tests were performed by impact pulsing with the help of specially designed facilities [12]. Main advantages of the method are as follows: operativity, usability, and minor dependence on the results on impact force.

Length of impact pulse is the informative parameter connecting the material strength with the characteristics of impact pulse. Following expression has helped determine the regularity of the influence of rock strength $\sigma_{c}$ on the period of impact pulse $\tau$ :

$\sigma_{c}=\left(\frac{\tau \rho_{2}}{K}-\frac{\rho_{2}}{\rho_{1} A C_{p} \sqrt{V_{0}}}\right)^{\frac{1}{2}}-B$,

where:

$\rho_{1}$ and $\rho_{2}-$ densities of the impactor material and the material under control respectively, $\mathrm{kg} / \mathrm{m}^{3}$;

$V_{0}$ - relative velocity of the bodies at the initial moment of plane contact with a spherical surface of the impactor, $\mathrm{m} / \mathrm{s}$;

$K=\frac{2.9 m}{V_{0} \sqrt{R}}-$ characteristic of the impactor;

$R$ - radius of a spherical surface of the impactor, $\mathrm{m}$;

$m$-impactor mass, $\mathrm{kg}$;

$C_{p}$ - velocity of the longitudinal wave of the impactor material, $\mathrm{m} / \mathrm{s}$;

$\sigma_{c}$ - ultimate uniaxial compression strength, $\mathrm{Pa}$;

$A$ and $B-$ constants for the represented rock.

In terms of mass express-determinations of strength parameters of rocks, empiric regression equations were applied. Each equation of parabolic type corresponded to the specific rock lithotype and reflected the interaction between the ultimate uniaxial compression strength and duration of impact pulse.

Experimental equipment DIKON developed with the participation of the authors was used as the control means.

\subsection{Supplemental information to the theory of scale effect consideration}

Currently we have accumulated great amount of mass characteristics of strength properties of different rock types. Methodologies of predicting distribution function, average value, and standard deviation of the strength of some groups of rocks on the basis of a logistic function of strength distribution of the known group of the tested specimens have been proposed. Such an approach is justified; it may be used to evaluate the scale factor on the basis of statistic theory of extreme values. The approach is based on the following statements of a statistic theory of scale factor: 
1) function of breaking probability for any material volume in terms of the given stressed state is a logistic curve;

2) assume that the specimen consists of some number of series-connected "primary" elements, which curve of strength distribution is known.

The specimen is considered to be broken when its weakest element is broken. From the statistic point of view, we have a case dealing with the study of distribution of the least order statistic of an ordered series under conditions that the initial totality has certain logistic distribution.

In terms of normalized distribution $F(t)=1 /\left(1+e^{-x}\right)$, minimal value of the sampling of volume $n$ has following distribution:

$\Phi(t)=1-\left(\frac{1}{1+e^{-t}}\right)^{n} ; t=\frac{(x-\mu)}{\delta}$,

where:

$\mu$ - parameter of shear (location);

$\delta$ - parameter of scale.

Average value and standard deviation of the distribution of minimum values (2) are defined according to formulas:

$\mu_{t}=-\sum_{k-1}^{n-1} \frac{1}{k} ; \quad \sigma_{t}\left\{\frac{\pi^{2}}{3}-\sum_{k-1}^{n-1} \frac{1}{k^{2}}\right\}^{\frac{1}{2}}$

For the initial variable $x$ of distribution, we obtain:

$\mu_{x}=\mu+\delta \cdot \mu_{t} ; \delta_{x}=\delta_{t} \cdot \delta$.

The formulas are applicable adequately in terms of low values of $n(n<50-100)$.

In terms of $n>100-200$, taking into consideration the simplifications and approximations, for average and standard deviations of the least order statistic of standardized variable $t=(x-\mu) / \delta$, we obtain:

$\mu_{x}=\mu-\delta\left[c+\ln (n-1)+\frac{1}{2(n-1)}\right] ; \quad \delta_{x}=\frac{\pi}{\sqrt{6}} \delta$.

Depending on value $n$, it is possible to use formulas (4) with special tables or asymptotic formulas (5) in terms of logistic distribution of strength parameters to evaluate average value and standard strength deviation of the specimens with the volume being by $n$ times higher than the initial one.

Transfer from the properties of rock in a specimen to the properties of rock mass at the same scale level means introduction of certain corrections. First of all, difference in scales is stipulated by fissility. If we determine fissility degree $N$ of the rock mass, it is possible to evaluate the mass strength with the help of empiric expressions. Such expressions are obtained according to the data on large volume of studies. For instance, paper [13] represents following expressions for sulphide ores:

$\sigma_{c}=\sigma_{c_{0}} \cdot\left[\frac{1.4}{(2+N)+0.3}\right]$,

where:

$\sigma_{c 0}-$ ultimate compression strength in a key specimen of rock (without fissures).

\section{Results and discussion}

\subsection{On the laboratory test procedure}

Measurements of the strength parameters of coals in the mode of uniaxial compression have demonstrated that temporary compression resistance determined according to current standards in terms of specimens of $40 \times 40 \times 40 \mathrm{~mm}$, differs from the values obtained in terms of the specimens with face dimensions of $80-150 \mathrm{~mm}$ by almost 2 times.

In this context, it has been identified that there is the ultimate dimension of a specimen, beginning from which its further increase does not result in the considerable changes of the strength indices. As for Western Donbas coals, a cube with edges of $100-150 \mathrm{~mm}$ is such an ultimate dimension. It means that to obtain real values of temporal compression resistance, it is required either to test coal specimens of the indicated dimensions or to define values of scale effect of strength for each mine and each mine seam with its further consideration in the results of standard tests. Figure 2 represents a graph of the obtained dependence.

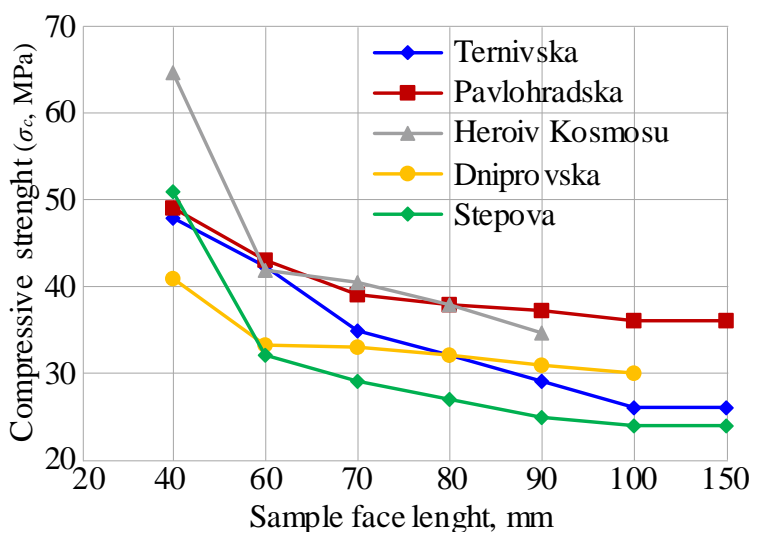

Figure 2. Dependence of temporal compression resistance of coals depending on the dimensions of sample faces for Western Donbas mines

When coal cutting resistance is being measured, value of component $P_{z}$ is of special interest. It has been identified that parameter $P_{z}$ depends considerably on the cutting depth. Moreover, maximum stability of indices is observed if cutting depth is $30 \mathrm{~mm}$. Figure 3 shows a graph of dependence of the averaged value of coal cutting resistance on the cutting depth.

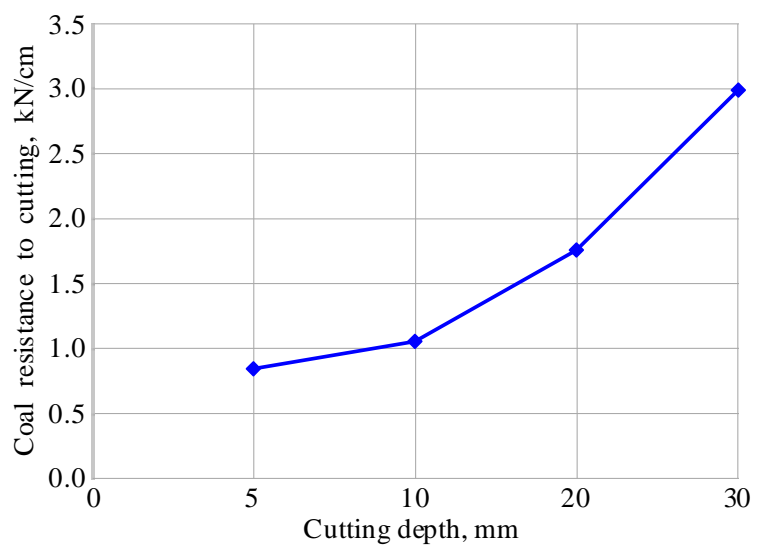

Figure 3. Dependence of coal cutting resistance on the cutting depth 
As an example, Figure 4 demonstrates a screenshot of the diagram of $z$-component of cutting force for the cutting depth of $30 \mathrm{~mm}$. The results indicate the necessity of either determining strength parameters of rocks in the conditions of natural occurrence or considering scale coefficients of strength.

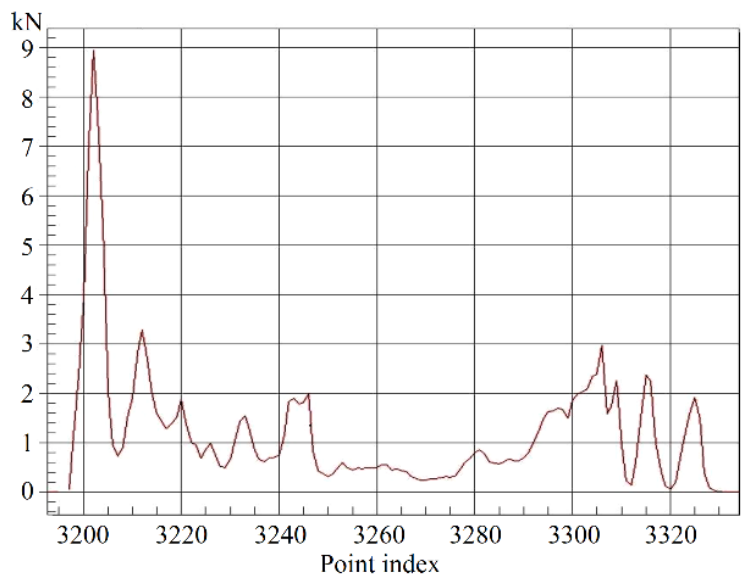

Figure 4. Screenshot of the diagram of force $P_{z}$ within a cutter in terms of cutting depth of $30 \mathrm{~mm}$ (quick view diagram)

Full-scale measurements of coal cutting resistance were carried out by the DMT GmbH Company. Thickness of coal seams $\mathrm{C}_{5}$ within the site under measurement was about $0.8 \mathrm{~m}$. The coal had no visible damages due to cutting and rock pressure action. The cutting was parallel to the mine working.

Average value of cutting force is $5.2 \mathrm{kN}$. In terms of relative units $(\mathrm{kN} / \mathrm{cm})$, a value of coal cutting resistance is $A=2.6 \mathrm{kN} / \mathrm{cm}$. According to the laboratory studies, i.e. [14], values of coal cutting resistance of seam $\mathrm{C}_{5}$ vary within the range of $2.8-5.4 \mathrm{kN} / \mathrm{cm}$. In this context, $\sigma_{c}$ varies within the range of 25-49 $\mathrm{MPa}$. It means that the scale effect is also characteristic for the parameter of "coal cutting resistance"; moreover, a value of scale coefficients for $A$ and $\sigma_{c}$ are close in their magnitude being equal to $0.49-0.58$ for the coal under analysis.

\subsection{On the evaluation of rock mass strength}

It is possible to exclude practically the influence of scale effect on the indices of rock strength by immediate measurements within the rock mass.

It has been already mentioned that the impact pulse method is applied in the construction industry to evaluate concrete strength in structures. We have refined upon that method having developed the corresponding equipment; thus, we propose to use them to control rock mass strength in mines.

Physical essence of the method is as follows: an anvil block with the spherical surface impacts the object surface; here all the impact energy (exclusive of heat losses) is consumed for elastic and plastic deformations of the material under analysis. As a result of plastic deformations, a concavity is formed; elastic deformations result in reactive force $F$.

The lower the strength properties of the environment are, the greater share of impact energy is spent for plastic deformations along with the increasing period of impacting. Growing material strength causes the growth of force $F$ value, and time of impact influence reduces. It means that in terms of normalized impact, a value of reactive force $F$ and duration of impact action are the indices of strength of the object under consideration, which experiences the impact.
However, it is difficult to measure technically force $F$ and time of impact action (impacting) directly.

To measure those values, the structure of anvil block includes an electromechanical transformer, which transforms mechanical energy of impact into electric pulse. Amplitude of that pulse $A$ is proportional to force $F$, and its duration $t$ is proportional to impacting time. Consequently, parameters $A$ and $t$ may act as the indirect characteristics of the rock strength.

As an informative parameter, the pulse amplitude is used in a series of industrial devices for express-identification of concrete quality. Such equipment requires devices with rigid stabilization of impacting speed by using impactors with calibrated spring-controlled energy accumulators. Such a complex mechanism with mobile elements is not an optimal technical solution for mine conditions. Consequently, we have used duration of impact pulse $\tau$ as an informative parameter.

Papers [11][12] substantiate the possibility of evaluating the rock strength in situ on the basis of measurements of impact pulse duration. To analyze the influence of a scale factor of strength on the impact pulse duration, the studies were carried out in terms of standard specimens and largesized samples. As an example, Figure 5 represents the results of tests for ferruginous quartzite.

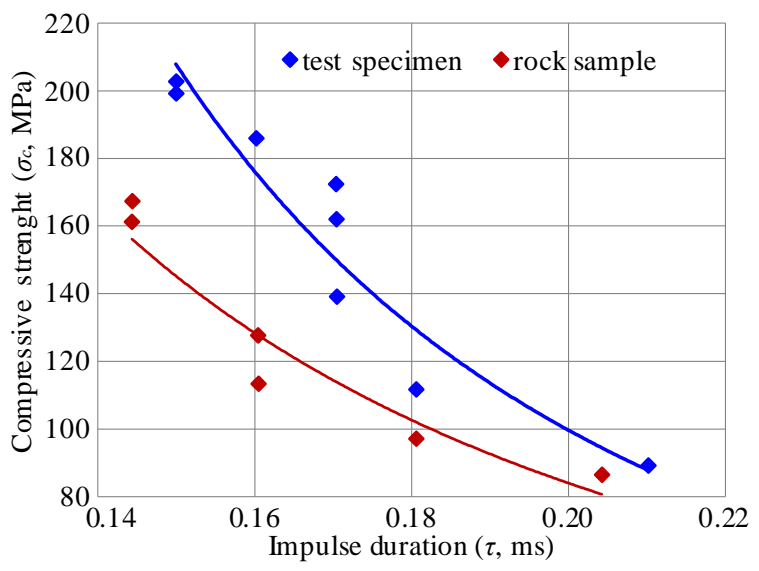

Figure 5. Dependence of ultimate compression strength on the impact pulse duration for specimens and samples of ferruginous quartzite

Following correlation dependences have been defined:

- for standard specimens $\sigma_{c}=1.637 \tau^{-2.553}$;

- for large-sized samples $\sigma_{c}=3.9428 \tau^{-1.901}$.

Similar studies have been carried out in terms of largesized samples and standard specimens of Western Donbas rocks: argillite, siltstone, and sandstone. The analysis was focused on rock strength $\sigma_{c}$, duration of impact pulse $\tau$, coefficient of structural weakening $K_{s w}$, coefficient $K_{\tau}$, and index of scale effect degree $f$.

Coefficient of scale effect was calculated according to formula:

$K_{\tau}=\frac{\tau_{2}}{\tau_{1}}$

where:

$\tau_{1}$ - duration of impact pulse of a standard specimen;

$\tau_{2}$-duration of impact pulse of a large-sized rock sample.

Indices of the scale effect degree were indicated basing on the following expressions: 
$f=\frac{\lg \sigma_{c_{1}}-\lg \sigma_{c_{2}}}{\lg S_{2}-\lg S_{1}} ;$

$f=\frac{\lg \tau_{1}-\lg \tau_{2}}{\lg S_{2}-\lg S_{1}}$,

where:

$\sigma_{c 1}$ - compression strength within the specimens with section area $S_{1}$;

$\sigma_{c 2}$-compression strength within the samples with section area $S_{2}$.

Coefficient of structural weakening is calculated according to formula:

$$
K_{S W}=\frac{\sigma_{c_{2}}}{\sigma_{c_{1}}} .
$$

Coefficient of structural weakening may be also calculated as the value being inverse to the coefficient of scale factor $K_{\tau}$ :

$$
K_{S W}=\frac{1}{K_{\tau}} .
$$

The proposed methodology is as follows. In terms of the represented group of standard specimens of one lithotype sampled from the area of future field studies, strength and duration of impact pulse are defined in the laboratory conditions. Then, large-sized samples of the same rocks are used to measure the impact pulse duration. Strength of the samples is calculated using the regularities identified earlier in the laboratory conditions. Table 1 shows the example of the results of such measurements for Western Donbas mines.

\begin{tabular}{|c|c|c|c|c|c|c|c|}
\hline \multirow{2}{*}{ Mine } & \multirow{2}{*}{ Lithotype } & \multicolumn{3}{|c|}{$\sigma_{c}, \mathrm{MPa}$} & \multirow{2}{*}{$K_{s w}$} & \multirow{2}{*}{$K_{\tau}$} & \multirow[b]{2}{*}{$n$} \\
\hline & & sample & specimen & calculated & & & \\
\hline \multirow{7}{*}{ Dniprovska } & sandstone & 9.1 & 13.8 & 21.9 & 0.66 & 1.9 & 0.15 \\
\hline & sandstone & 19.3 & 26.7 & 29.4 & 0.72 & 1.4 & 0.12 \\
\hline & sandstone & 17.2 & 30.0 & 29.4 & 0.57 & 1.5 & 0.21 \\
\hline & sandstone & 19.3 & 20.5 & 22.4 & 0.94 & 1.5 & 0.03 \\
\hline & argillite & 6.1 & 13.4 & 18.5 & 0.45 & 1.4 & 0.41 \\
\hline & argillite & 9.7 & 20.3 & 24.1 & 0.48 & 1.6 & 0.23 \\
\hline & siltstone & 6.9 & 11.4 & 18.3 & 0.6 & 1.4 & 0.31 \\
\hline \multirow{2}{*}{ Samarska } & siltstone & 2.7 & 13.7 & 15.7 & 0.2 & 1.6 & 0.74 \\
\hline & siltstone & 4.0 & 12.1 & 22.4 & 0.34 & 1.7 & 0.43 \\
\hline Stashkova & sandstone & 10.1 & 17.3 & 22.3 & 0.58 & 2.3 & 0.23 \\
\hline $\begin{array}{l}\text { Zakhidno- } \\
\text { Donbaska }\end{array}$ & sandstone & 11.8 & 24.4 & 29.4 & 0.48 & 2.0 & 0.34 \\
\hline \multirow{2}{*}{ Yuvileina } & siltstone & 9.6 & 21.0 & 25.2 & 0.63 & 1.4 & 0.65 \\
\hline & siltstone & 8.0 & 14.0 & 19.6 & 0.57 & 1.6 & 0.22 \\
\hline Stepova & argillite & 6.1 & 15.7 & 18.2 & 0.39 & 1.6 & 0.35 \\
\hline
\end{tabular}

Table 1. Mechanical properties of specimens and samples of rocks taken within the rock mass

Table 1 demonstrates that the method of impact pulse gives somehow underestimated values of compressive strength while the computational method gives the overestimated values (sometimes even considerably overestimated ones). However, the nature of the ratio of ultimate strength determined by different methods for all mines and for all rocks is preserved. Decreased values of ultimate strength defined by impact pulsing is explained by the fact that the measurements have been performed in terms of large-sized samples. That is explained by the influence of scale effect.

The impact pulse method has been applied to study shapeless samples of very hard rock. It has been identified that despite high density, its strength also depends considerably on sample sizes; moreover, high reliability of data is possible in terms of volumes $V$ being greater than $7000 \mathrm{~cm}^{3}$ (Fig. 6).

Following correlation dependences have been specified for each group of hard rock:

$$
\begin{aligned}
& \text { - albitites } \sigma_{c}=317.11 e^{-0.021 V} ; \\
& - \text { migmatites } \sigma_{c}=202.64 e^{-0.021 V} ; \\
& \text { - granites } \sigma_{c}=126.89 e^{-0.026 V} .
\end{aligned}
$$

\section{Conclusions}

It has been determined that basic physical and mechanical parameter of rock (i.e. strength) depends considerably on the size of specimens under analysis. That is stipulated by significant porosity and fissility of the rocks. The error decreases along with the increasing specimen size.

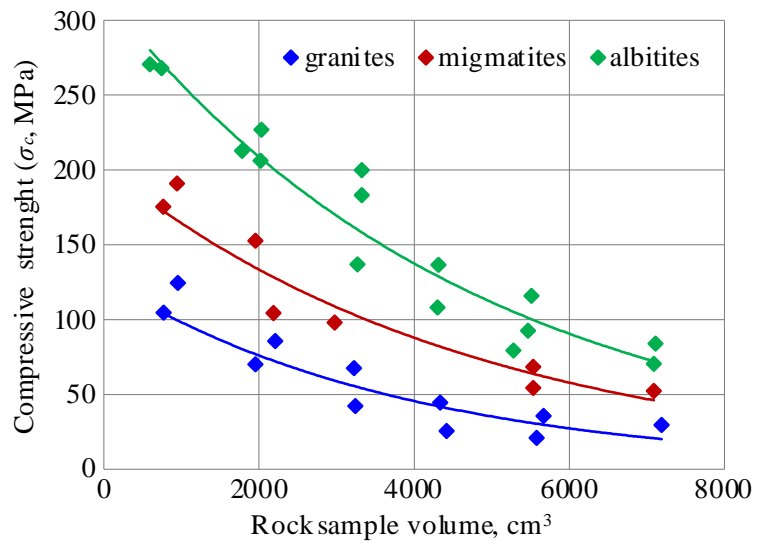

Figure 6. Dependence of the strength of hard rock on its volume

There is certain ultimate size, beginning from which its further increase does not result in the considerable changes in the strength indices. For instance, in terms of Western Donbas coals, that is a cube with the faces of not less than $100 \mathrm{~mm}$.

Despite its considerable density, great scale effect is observed in very hard rock as well. That is stipulated by the available zones with anomalously high porosity (being by 2-3 times higher than the standard values) and coarse grains. Thus, minimal sizes of sample faces for very hard rock should be not less than 150-200 mm. Tests of such specimens are rather labour-intense; they are often beyond the capacities of standard equipment. 
Structural anomalies require application of the methods, which make it possible to evaluate their strength immediately within the rock mass. The method of impact pulse is among those techniques.

To consider scale effect of strength, methodology and equipment for express-control of rock mass strength by impact pulsing have been improved and adapted. The methodology is based on the determined correlation dependences between the indices of rock strength and duration of impact pulse obtained in terms of standard specimens and unprocessed large-sized samples of rocks.

Scale coefficients, which take into consideration different rock properties in terms of specimens and large-sized samples, make it possible to evaluate strength characteristics of rocks immediately within the rock mass.

\section{Acknowledgements}

The results are a part of the program "Promoting the development of priority research areas" (KPKVK 6541230) of state funding for the National Academy of Sciences of Ukraine.

\section{References}

[1] Protosenya, A.G. (2016). Determination of the scale effect of the strength properties of a fractured rock massif. Izvestiya TulGY. Nauki o Zemle, (1), 167-176.

[2] Jian Ping, Y., Wei Zhong, C., Dian Sen, Y., \& Jing Qiang, Y. (2015). Numerical determination of strength and deformability of fractured rock mass by FEM modeling. Computers and Geotechnics, (64), 20-31. https://doi.org/10.1016/j.compgeo.2014.10.011

[3] Wittke, W. (2014). Rock mechanics based on an anisotropic jointed rock model (AJRM). Berlin, Germany: Wilhelm Ernst \& Sohn. https://doi.org/10.1002/9783433604281

\section{До методики врахування масштабного ефекту міцності гірських порід}

\section{С. Скіпочка, О. Круковський, Т. Паламарчук, Л. Прохорець}

Мета. Удосконалення методики врахування впливу масштабного ефекту, шляхом переходу до оцінки міцності порід безпосередньо в масиві.

Методика. У роботі використані методи критичного аналізу, теоретичні та експериментальні методи досліджень в лабораторних і шахтних умовах. Зокрема, положення ймовірносно-статистичної теорії, стандартні випробування зразків гірських порід на міцність, лабораторні дослідження опірності вугілля різанню, оцінка міцності порід в масиві методом ударного імпульсу.

Результати. Встановлено, що міцність порід істотно залежить від розмірів досліджуваних зразків. Це обумовлено високою пористістю і тріщинуватістю матеріалу. Похибка вимірювань зменшується зі збільшенням розміру зразка. Існує граничний розмір, починаючи з якого подальше його збільшення не призводить до суттєвих змін показника міцності. Наприклад, для вугілля Західного Донбасу таким граничним розміром є куб з гранями не менше 100 мм. Показано, що незважаючи на високу щільність значний масштабний ефект спостерігається і в скельних породах, який обумовлений наявністю зон з аномально високою пористістю і великою зернистістю. Мінімальний розмір зразків для скельних порід має бути не менше 150-200 мм. Випробування таких зразків трудомісткі й часто виходять за межі можливостей серійного обладнання. Зроблено висновок, що структурні аномалії порід вимагають використання методів, які дозволять оцінювати їх міцність безпосередньо в масиві, одним з яких є метод ударного імпульсу.

Наукова новизна. Визначено мінімальні розміри зразків скельних порід і порід вугільних формацій, що дозволяють виключити вплив масштабного ефекту міцності. Одержано кореляційні залежності, що зв'язують інформативний параметр методу ударного імпульсу з міцністю різних літотипів гірських порід.

Практична значимість. Вдосконалено методику врахування масштабного ефекту міцності при лабораторних дослідженнях та оцінки міцності гірських порід в масиві.

Ключові слова: гірські породи, міџність, опірність різанню, масштабний ефект, лабораторні вимірювання, шахтний контроль

\section{К методике учета масштабного эффекта прочности горных пород}

\section{С. Скипочка, А. Круковский, Т. Паламарчук, Л. Прохорец}

Цель. Усовершенствование методики учета влияния масштабного эффекта, путем перехода к оценке прочности пород непосредственно в массиве.

Методика. В работе использованы методы критического анализа, теоретические и экспериментальные методы исследований в лабораторных и шахтных условиях. В частности, положения вероятностно-статистической теории, стандартные испытания образцов горных пород на прочность, лабораторные исследования сопротивляемости углей резанию, оценка прочности пород методом ударного импульса в массиве. 
Результаты. Установлено, что прочность пород существенно зависит от размеров испытуемых образцов. Это обусловлено высокой пористостью и трещиноватостью материала. Погрешность измерений уменьшается с увеличением размера образца. Существует предельный размер, начиная с которого дальнейшее его увеличение не приводит к существенным изменениям показателя прочности. Например, для углей Западного Донбасса таким предельным размером является куб с гранями не менее 100 мм. Показано, что несмотря на высокую плотность значительный масштабный эффект наблюдается и в скальных породах, который обусловлен наличием зон с аномально высокой пористостью и крупной зернистостью. Определено, что минимальные размеры грани образцов для скальных пород должны быть не менее 150-200 мм. Испытания таких образцов трудоемки и часто выходят за пределы возможностей серийного оборудования. Сделан вывод, что структурные аномалии пород требуют использования методов, которые позволяют оценивать их прочность непосредственно в массиве, одним из которых является метод ударного импульса.

Научная новизна. Определены минимальные размеры образцов скальных пород и пород угольных формаций, позволяющие исключить влияние масштабного эффекта прочности. Получены корреляционные зависимости, связывающие информативный параметр метода ударного импульса с прочностью различных литотипов горных пород.

Практическая значимость. Усовершенствована методика учета масштабного эффекта прочности при лабораторных исследованиях и оценки прочности горных пород в массиве.

Ключевые слова: горные породы, прочность, сопротивляемость резанию, масштабный эффект, лабораторные измерения, шахтный контроль

\section{Article info}

Received: 26 March 2020

Accepted: 26 October 2020

Available online: 7 December 2020 